\title{
Sulfoacetate generated by Rhodopseudomonas palustris from taurine
}

\begin{abstract}
Genes thought to encode (a) the regulator of taurine catabolism under carbon-limiting or nitrogen-limiting conditions and (b) taurine dehydrogenase were found in the genome of Rhodopseudomonas palustris. The organism utilized taurine quantitatively as a sole source of nitrogen (but not of carbon) for aerobic and photoheterotrophic growth. No sulfate was released, and the C-sulfonate bond was recovered stoichiometrically as sulfoacetate, which was identified by mass spectrometry. An inducible sulfoacetaldehyde dehydrogenase was detected. $R$. palustris thus contains a pathway to generate a natural product that was previously believed to be formed solely from sulfoquinovose.
\end{abstract}

Keywords Sulfoacetate formation - Taurine deamination $\cdot$ Taurine dehydrogenase $\cdot$ Sulfoacetaldehyde dehydrogenase $\cdot$ Rhodopseudomonas palustris

\section{Introduction}

Organosulfonate compounds, those containing the stable $\mathrm{C}-\mathrm{SO}_{3}$-group, are widespread in nature, although only a limited number of individual compounds is known (Cook and Denger 2002; Lie et al. 1998). Taurine (2-aminoethanesulfonate: Fig. 1) is the major organic solute found in mammals (Huxtable 1992). The plant sulfolipid, which contains a sulfonated derivative of glucose (sulfoquino-

The senior author (AMC) would like to express his thanks for the rewarding experience of doing postdoctoral research in the laboratory of Prof. H.-G. Schlegel.

K. Denger $\cdot$ S. Weinitschke $\cdot$ A. M. Cook (四)

Fachbereich Biologie der Universität Konstanz,

78457 Konstanz, Germany

Tel.: +49-7531-884247, Fax: +49-7531-882966,

e-mail: alasdair.cook@uni-konstanz.de

K. Hollemeyer

Institut für Technische Biochemie, Universität des Saarlandes, P.O. Box 151150, 66041 Saarbrücken, Germany vose), is a key component of the thylakoid membrane (Benson 1963; Roy et al. 2003). Sulfoquinovose can be degraded via sulfoacetate (Martelli and Benson 1964; see also Roy et al. 2003), and sulfoacetate has been taken as an indicator of the degradation of the plant sulfolipid (Cook and Denger 2002; Lie et al. 1998).

Two major fates of taurine are well known in bacteria. Firstly, there is dissimilation of the carbon atoms via sulfoacetaldehyde and sulfoacetaldehyde acetyltransferase (Xsc) [EC 2.3.3.15] in aerobic and anaerobic bacteria. Secondly, there is the assimilation of sulfonate sulfur after either the reaction of Xsc in anaerobes or of taurine dioxygenase (TauD) [EC 1.14.11.17] in aerobes (Cook and Denger 2002; Kertesz 2000). Two different reactions are known to generate sulfoacetaldehyde from taurine, taurine:pyruvate aminotransferase (Tpa) [EC 2.6.1.77] in, e.g. Bilophila wadsworthia and Rhodococcus opacus (Cook and Denger 2002; Denger et al. 2004), and taurine:ferricytochrome $c$ oxidoreductase (presumably TauXY, tentatively [EC 1.4.2]) in, e.g. Achromobacter xylosoxidans and Paracoccus denitrificans (Brüggemann et al. 2004; Cook and Denger 2002; Ruff et al. 2003). There are three characterized subgroups of $x s c$ genes, but a second group is anticipated for which no activity in cell extracts is known (Brüggemann et al. 2004; Cook and Denger 2002; Ruff et al. 2003) and which may be found in the newly sequenced genomes.

Taurine also serves as a nitrogen source for growth, a process usually followed simultaneously by the degradation of the compound as a source of carbon (e.g. Chien et al. 1999). R. opacus utilizes taurine as a sole source of nitrogen for growth in the presence of the carbon source glucose, and the complete dissimilatory pathway for taurine is induced by the organism to deaminate taurine, although regulated at a different level of expression (Denger et al. 2004).

Analysis of the genome of Rhodopseudomonas palustris (Larimer et al. 2004) revealed the presence of genes that resembled those presumed to encode TauR (RPA0105) (Fig. 1), the transcriptional regulator of taurine catabolism, and TauXY (RPA0112a-0113) (Brüggemann et al. 
Fig. 1 Genes from the genome of Rhodopseudomonas palustris, which led to the prediction that the organism utilizes taurine. A The putative and confirmed reactions in the assimilatory deamination of taurine. B The genetic locus shows four genes (RPA0105 and RPA0111-0113) annotated in the genome project (Larimer et al. 2004), our tentative addition (RPA0112a, bases 129624130027; designated Rpal1394 in the draft sequence), and the direction of transcription. There is a termination loop downstream of RPA0113 and RPA0110 is encoded on the opposite strand, so any gene expression at this locus is limited to the two illustrated pairs of genes. The annotation betB (a eukaryotic-type gene!) derives from the genome project; the others are the authors' hypotheses
A
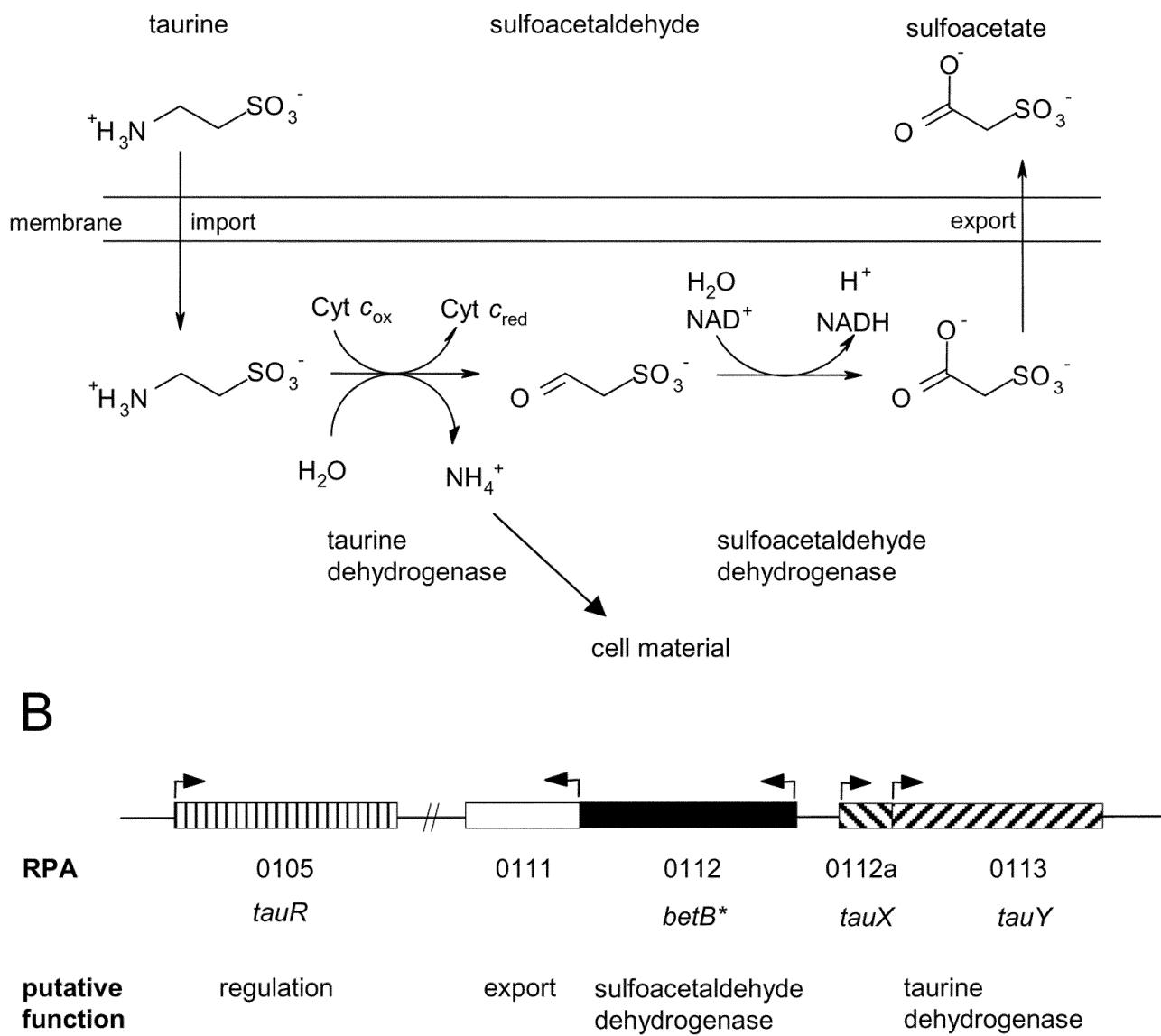

2004) but no gene encoding Xsc. Since the organism did not utilize taurine as a source of carbon (see below), there was no new class of Xsc present. However, the organism did utilize taurine as a sole source of nitrogen for growth in the presence of an added source of carbon, although the sulfonate sulfur was not released as an inorganic species (see below), in contrast to the behaviour of $R$. opacus (Denger et al. 2004).

We now report that $R$. palustris oxidatively deaminates taurine to sulfoacetaldehyde. The latter is quantitatively oxidized to sulfoacetate by an NAD-coupled sulfoacetaldehyde dehydrogenase, which has not been observed previously.

\section{Materials and methods}

Organism, growth media, and growth conditions

R. palustris CGA009 was kindly provided by C.S. Harwood (Department of Microbiology, University of Iowa, USA). A mineral-salts medium buffered with $50 \mathrm{mM}$ potassium phosphate, $\mathrm{pH} 7.2$, was used for carbon-limited growth (Thurnheer et al. 1986); taurine or acetate was supplied at $20 \mathrm{mM}, \mathrm{D}, \mathrm{L}-\mathrm{malate}$ at $10 \mathrm{mM}$. This medium was adapted for nitrogen-limited growth by eliminating the standard $20 \mathrm{mM}$ ammonium chloride and replacing it with $2 \mathrm{mM}$ taurine (or $2 \mathrm{mM}$ ammonium chloride); the carbon source was $10 \mathrm{mM}$ D,L-malate. Growth experiments were done with $5-\mathrm{ml}$ cultures in 30-ml tubes incubated on a roller, or with 50-ml cultures in 300-ml Erlenmeyer flasks on a rotary shaker at $30^{\circ} \mathrm{C}$ in the dark. Cells from which crude extract was to be prepared were grown in 500-ml cultures in 5-1 Erlenmeyer flasks. Photoheterotrophic growth was followed in anoxic, phosphatebuffered $(30 \mathrm{mM}, \mathrm{pH} 6.8)$, mineral-salts medium (ammonium sulfate, $7.5 \mathrm{mM}$; magnesium sulfate, $0.8 \mathrm{mM}$; calcium chloride, $0.35 \mathrm{mM}$ ), which was supplemented with a trace-elements solution (Thurnheer et al. 1986), vitamins (Pfennig 1978) and D,L-malate $(20 \mathrm{mM})$ or $20 \mathrm{mM}$ taurine as sole source of carbon. Cultures were incubated at room temperature under an atmosphere of nitrogen in the light (25-W tungsten-filament lamp). This malate-containing medium was modified (taurine replaced ammonium sulfate) to test taurine as a sole source of combined nitrogen under photoheterotrophic conditions.

\section{Experiments with cell suspensions}

Cultures $(5 \mathrm{ml})$ were centrifuged $(20,000 \times \mathrm{g}, 3 \mathrm{~min}$, room temperature) and the pellets resuspended in $200 \mu 1$ potassium 
phosphate buffer $(50 \mathrm{mM}, \mathrm{pH} 7.2)$. These suspensions were supplemented with taurine to a final concentration of $12 \mathrm{mM}$, incubated for $2 \mathrm{~h}$ at $37^{\circ} \mathrm{C}$, and analyzed for sulfoacetate.

Preparation of cell-free extracts, and enzyme assays

Cells were harvested at the end of the exponential growth phase by centrifugation $\left(20,000 \times g, 15 \mathrm{~min}, 4^{\circ} \mathrm{C}\right)$, washed

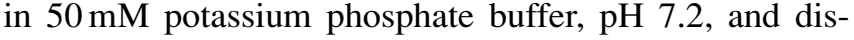
rupted by five passages through a French pressure cell set at $138 \mathrm{MPa}$.

Taurine dehydrogenase (TDH) was assayed spectrophotometrically as the taurine-dependent reduction of cytochrome $c$ (or dichlorophenol indophenol (DCPIP), $\mathrm{NAD}^{+}$or $\mathrm{NADP}^{+}$) in $50 \mathrm{mM}$ potassium phosphate buffer, $\mathrm{pH} 7.5$ or $\mathrm{pH} 6.0$, or Tris/HCl-buffer, $\mathrm{pH} 9.0$ (Brüggemann et al. 2004). Taurine:pyruvate aminotransferase (Tpa) was assayed discontinuously as the pyruvate-dependent disappearance of taurine, as described elsewhere (Brüggemann et al. 2004).

Sulfoacetaldehyde dehydrogenase was routinely quantified spectrophotometrically $(340 \mathrm{~nm})$ as the sulfoacetaldehyde-dependent reduction of $\mathrm{NAD}^{+}$. The reaction mixture contained in $1 \mathrm{ml}: 50 \mu \mathrm{mol}$ potassium phosphate buffer, $\mathrm{pH} 7.5$, including $5 \mathrm{mM} \mathrm{MgCl}_{2}, 2 \mu$ mol $\mathrm{NAD}^{+}$, $0.1-0.5 \mathrm{mg}$ protein, and $0.4 \mu \mathrm{mol}$ sulfoacetaldehyde with which the reaction was started. The enzyme was occasionally assayed discontinuously. The reaction mixture was incubated at $30^{\circ} \mathrm{C}$, and samples $(200 \mu \mathrm{l})$ were transferred at intervals to acetonitrile $50 \mu \mathrm{l}$ to stop the reaction. This material was subject to analyses for sulfoacetate by ion chromatography.

\section{Analytical methods}

Growth was followed as turbidity $\left(\mathrm{OD}_{580}=1.0=250 \mathrm{mg}\right.$ protein $\mathrm{l}^{-1}$ ) and quantified as protein in a Lowry-type reaction (Cook and Hütter 1981). Reversed-phase chromatography was used to quantify taurine (Laue et al. 1997) or sulfoacetaldehyde (Cunningham et al. 1998) after derivatization. Sulfate was determined turbidimetrically as a suspension of $\mathrm{BaSO}_{4}$ (Sörbo 1987). Ammonium ion was assayed colorimetrically by the Berthelot reaction (Gesellschaft Deutscher Chemiker 1996). Sulfoacetate was quantified by ion chromatography with suppression (Sykam, Fürstenfeldbruck, Germany) on an anion exchange column (LCA A03) with isocratic elution $(0.53 \mathrm{~g}$ sodium carbonate, $50 \mathrm{mg}$ 4-hydroxybenzonitrile, and $100 \mathrm{ml}$ acetonitrile made up to 11 with distilled water) and conductivity detection. The identity of sulfoacetate was confirmed by matrix-assisted, laser-desorption ionization timeof-flight mass spectrometry (MALDI-TOF-MS) in the negative ion mode with a matrix of 4-hydroxy- $\alpha$-cyanocinnamic acid. Values of apparent $K_{\mathrm{m}}\left(K_{\mathrm{m}}\right.$ app) were derived by hyperbolic curve-fitting as cited elsewhere (Ruff et al. 2003). SDS-PAGE and staining were done by standard methods (Laemmli 1970).
Chemicals

The preparation of sulfoacetaldehyde, as the bisulfite addition complex, was described elsewhere (Denger et al. 2001). Sulfoacetate was purchased from Fisher Scientific (Schwerte, Germany). Commercial chemicals were of the highest purity available and were purchased from Fluka, Merck, Serva or Sigma.

\section{Results and discussion}

Growth physiology and identification of sulfoacetate

$R$. palustris grew on malate or acetate as sole source of carbon and energy for aerobic growth with a molar yield of $3.8 \mathrm{~g}$ protein $/ \mathrm{mol} \mathrm{C}$, a value that indicates mass balance (Cook 1987). Taurine was not utilized. Malate supported growth of $R$. palustris under photoheterotrophic conditions; taurine did not.
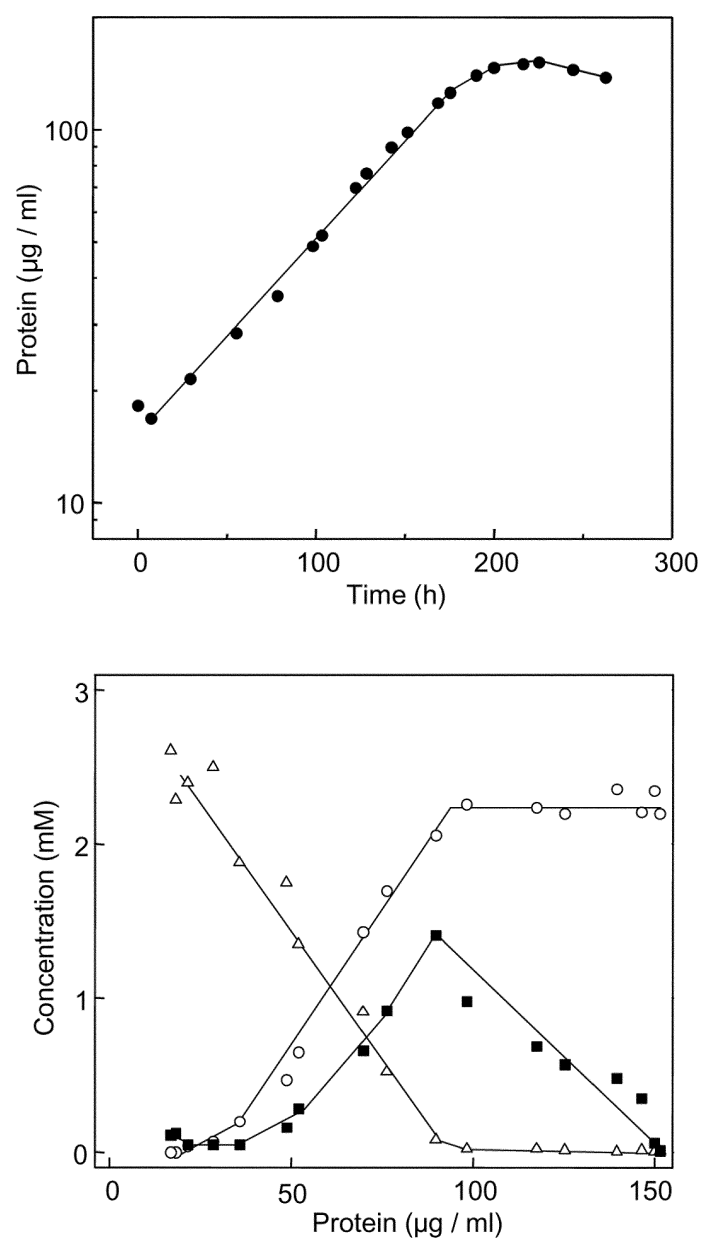

Fig. 2 Growth of $R$. palustris with taurine as the sole added source of combined nitrogen. A representative growth curve is shown in the upper graph. The lower graph shows the corresponding concentrations of taurine (open triangles), sulfoacetate (open circles) and ammonia (filled squares) as a function of growth 
Taurine was then tested as a sole source of nitrogen for aerobic growth with malate as the carbon source (Fig. 2). Taurine disappeared during the experiment, but more rapidly than the culture grew. Correspondingly, ammonia was released transiently into the medium until taurine disappeared, after which the culture utilized the ammonium ion for growth. The molar growth yield of about $58 \mathrm{~g}$ protein/mol N, the same as observed with ammonium as the sole source of nitrogen, indicated total recovery of the taurine-nitrogen in cell material (Cook 1987). The specific growth rate $(\mu), 0.013 \mathrm{~h}^{-1}$, allowed the specific deamination rate of taurine during growth to be estimated, namely $\geq 0.06 \mathrm{mkat} / \mathrm{kg}$ protein.

The fate of the remainder of the taurine molecule was initially unclear, because no sulfate was released during growth (not shown). The lack of sulfate, and thus, under oxic conditions, of sulfite, indicated that the $\mathrm{C}_{-} \mathrm{SO}_{3}$-bond was not cleaved (Fig. 1). It was presumed that the organism would not excrete the chemically reactive sulfoacetaldehyde, and this was confirmed experimentally (not shown). Under oxic conditions, oxidation of the aldehyde to the acid was predicted, and tentatively confirmed by observing release of a compound that co-eluted with sulfoacetate from the ion chromatographic column. The tentatively identified sulfoacetate was released stoichiometrically and concomitant with the disappearance of taurine (Fig. 2). No sulfoacetate was formed during growth with ammonium ion as the nitrogen source.

The identification of sulfoacetate was confirmed by MALDI-TOF-MS. The base peak $(\mathrm{m} / \mathrm{z})$ for sulfoacetate was 139 (M-1), which was found after growth with taurine as nitrogen source, whereas taurine $(m / z=124(\mathrm{M}-1))$ was absent from the culture supernatant after growth.

$R$. palustris also grew with taurine as sole source of combined nitrogen under photoheterotrophic conditions. $R$. palustris did not fix $\mathrm{N}_{2}$ for growth under the oxic and anoxic conditions used here.

Enzymes detected and the transformation pathway

Suspensions of cells grown on taurine as the sole source of nitrogen converted taurine to sulfoacetate, whereas cells grown on ammonium did not. The enzymes involved in the biotransformation were apparently inducible, as predicted (Fig. 1).

Extracts were prepared from cells of $R$. palustris grown on taurine or on ammonium ion as the sole source of nitrogen. Neither taurine dehydrogenase nor taurine transaminase was detected to yield the substrate for the second enzyme in the pathway, but, given good candidate genes for the former (Fig. 1; see also Brüggemann et al. 2004), the activity of taurine dehydrogenase in induced whole cells of $R$. palustris was assumed.

Extracts of taurine-grown cells were able to catalyze the oxidation of sulfoacetaldehyde to sulfoacetate. There was no formation of sulfoacetate without extract, sulfoacetaldehyde, or $\mathrm{NAD}^{+}$; thus, sulfoacetaldehyde did not oxidize spontaneously under these conditions (Fig. 3). The

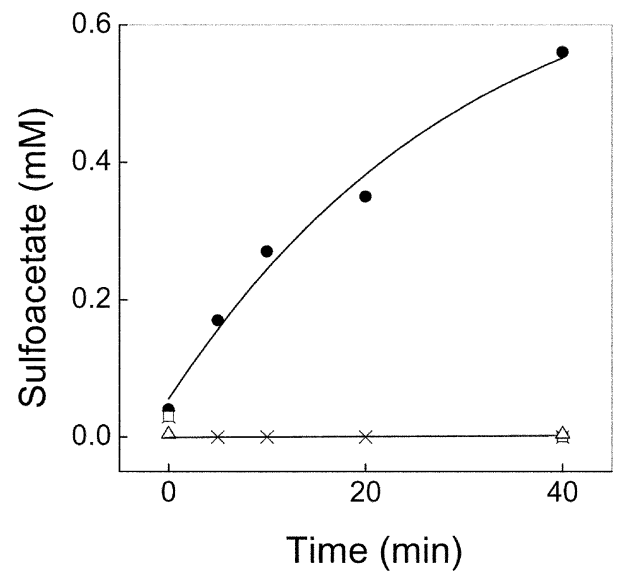

Fig. 3 Formation of sulfoacetate from sulfoacetaldehyde in cell extracts of $R$. palustris (filled circles). Control experiments were done in the absence of enzymes $(X)$, in the absence of sulfoacetaldehyde (open squares) or in the absence of $\mathrm{NAD}^{+}$(open triangles)

routine photometric test showed extract-dependent and substrate-dependent reduction of NAD. The specific activity was about $0.4 \mathrm{mkat} / \mathrm{kg}$ protein, which is sufficient to explain the growth rate (see above). There was no reaction with boiled extract or with extract of ammonia-grown cells. NAD could be replaced by NADP with a specific activity of about $70 \%$ of the activity with NAD. Values of $K_{\mathrm{m}}{ }^{\text {app }}$ for sulfoacetaldehyde dehydrogenase were determined: for NAD, $0.25 \pm 0.02 \mathrm{mM}$, and for sulfoacetaldehyde, $26 \pm 3.4 \mu \mathrm{M}$. The oxidation of similar, derivatized aldehydes is known (Murphy et al. 2001).

\section{Significance of the findings}

Until now, sulfoquinovose was regarded as the source of biological sulfoacetate (Martelli and Benson 1964). The present data thus demonstrate a novel biological source for sulfoacetate, taurine. Taurine, like sulfoquinovose, is widespread (Huxtable 1992) and subject to many known microbiological fates (Cook and Denger 2002; Kertesz 2000). It seems logical that yet another nutritional macroelement in taurine, nitrogen, can be used individually, as in this study, as well as in combination with, e.g. the carbon and energy source, as in Rhodococcus spp. (Denger et al. 2004). Sulfoacetate, analogous to taurine, is subject to a wide range of fates in aerobic and anaerobic microorganisms (Cook and Denger 2002).

A major factor in this short metabolic sequence (Fig. 1) is membrane transport. Transport of sulfonates across membranes is axiomatic (Graham et al. 2002), therefore $R$. palustris requires an import system and an export system (Fig. 1). Evidence for both ATP-binding-cassette transporters and TRAP-transporters for the uptake of taurine has been presented (Brüggemann et al. 2004; Kertesz 2001). However, since no significant homologues were found in the genome of $R$. palustris, the natures of the up- 
take systems for taurine and the exporter of sulfoacetate are open to conjecture (Fig. 1).

Acknowledgements We are grateful to C.M. Harwood for supplying the organism and for discussions. The project was funded by the University of Konstanz.

\section{References}

Benson AA (1963) The plant sulfolipid. Adv Lipid Res 1:387-394

Brüggemann C, Denger K, Cook AM, Ruff J (2004) Enzymes and genes of taurine and isethionate dissimilation in Paracoccus denitrificans. Microbiology (Reading, UK) 150:805-816

Chien C-C, Leadbetter ER, Godchaux W III (1999) Rhodococcus spp. utilize taurine (2-aminoethanesulfonate) as sole source of carbon, energy, nitrogen and sulfur for aerobic respiratory growth. FEMS Microbiol Lett 176:333-337

Cook AM (1987) Biodegradation of $s$-triazine xenobiotics. FEMS Microbiol Rev 46:93-116

Cook AM, Denger K (2002) Dissimilation of the $C_{2}$ sulfonates. Arch Microbiol 179:1-6

Cook AM, Hütter R (1981) $s$-Triazines as nitrogen sources for bacteria. J Agric Food Chem 29:1135-1143

Cunningham C, Tipton KF, Dixon HBF (1998) Conversion of taurine into $\mathrm{N}$-chlorotaurine (taurine chloramine) and sulphoacetaldehyde in response to oxidative stress. Biochem J 330: 939-945

Denger K, Ruff J, Rein U, Cook AM (2001) Sulfoacetaldehyde sulfo-lyase [EC 4.4.1.12] from Desulfonispora thiosulfatigenes: purification, properties and primary structure. Biochem J 357:581-586

Denger K, Ruff J, Schleheck D, Cook AM (2004) Rhodococcus opacus expresses the $x s c$ gene to utilize taurine as a carbon source or as a nitrogen source but not as a sulfur source. Microbiology 150:1859-1867

Gesellschaft Deutscher Chemiker (1996) German standard methods for the laboratory examination of water, waste water and sludge. VCH, Weinheim

Graham DE, Xu H, White RH (2002) Identification of coenzyme M biosynthetic phosphosulfolactate synthase: a new family of sulfonate biosynthesizing enzymes. J Biol Chem 277:1342113429
Huxtable RJ (1992) Physiological actions of taurine. Physiol Rev 72:101-163

Kertesz MA (2000) Riding the sulfur cycle - metabolism of sulfonates and sulfate esters in Gram-negative bacteria. FEMS Microbiol Rev 24:135-175

Kertesz MA (2001) Bacterial transporters for sulfate and organosulfur compounds. Res Microbiol 152:279-290

Laemmli UK (1970) Cleavage of structural proteins during the assembly of the head of bacteriophage T4. Nature (London) 227:680-685

Larimer FW et al (2004) Complete genome sequence of the metabolically versatile photosynthetic bacterium Rhodopseudomonas palustris. Nat Biotechnol 22:55-61

Laue H, Denger K, Cook AM (1997) Taurine reduction in anaerobic respiration of Bilophila wadsworthia RZATAU. Appl Environ Microbiol 63:2016-2021

Lie TL, Leadbetter JR, Leadbetter ER (1998) Metabolism of sulfonic acids and other organosulfur compounds by sulfatereducing bacteria. Geomicrobiol J 15:135-149

Martelli HL, Benson AA (1964) Sulfocarbohydrate metabolism. 1. Bacterial production and utilization of sulfoacetate. Biochim Biophys Acta 93:169-171

Murphy CD, Moss SJ, O'Hagan D (2001) Isolation of an aldehyde dehydrogenase involved in the oxidation of fluoroacetaldehyde to fluoroacetate in Streptomyces cattleya. Appl Environ Microbiol 67:4919-4921

Pfennig N (1978) Rhodocyclus purpureus gen. nov. sp. nov., a ring-shaped, vitamin $\mathrm{B}_{12}$-requiring member of the family Rhodospirillaceae. Int J Syst Bacteriol 28:283-288

Roy AB, Hewlins MJE, Ellis AJ, Harwood JL, White GF (2003) Glycolytic breakdown of sulfoquinovose in bacteria: a missing link in the sulfur cycle. Appl Environ Microbiol 69:6434-6441

Ruff J, Denger K, Cook AM (2003) Sulphoacetaldehyde acetyltransferase yields acetyl phosphate: purification from Alcaligenes defragrans and gene clusters in taurine degradation. Biochem J 369:275-285

Sörbo B (1987) Sulfate: turbidimetric and nephelometric methods. Methods Enzymol 143:3-6

Thurnheer T, Köhler T, Cook AM, Leisinger T (1986) Orthanilic acid and analogues as carbon sources for bacteria: growth physiology and enzymic desulphonation. J Gen Microbiol 132: $1215-1220$ 